CARADDE: Jurnal Pengabdian Kepada Masyarakat
$\begin{gathered}\text { https://journal.ilininstitute.com/index.php/caradde } \\ \text { Volume 2 I Nomor 1 I Agustus I2019 } \\ \text { e-ISSN: 2621-7910 dan p-ISSN: 2621-7961 }\end{gathered}$

\title{
PKM Ekonomi Produktif Melalui Technopreneurhip Bagi Guru di SMK Bisnis Dan Teknologi
}

\section{Sugeng Haryono ${ }^{1,}$, Prasetio Ariwibowo ${ }^{2,}$, Tjipto Djuhartono ${ }^{3,}$}

\begin{tabular}{l}
\hline Keywords: \\
Technopreneurship; \\
Kewirausahaan; \\
Civitas akademik, \\
SMKS Bisnis dan Teknologi \\
Bekasi \\
Corespondensi Author \\
Ekonomi, Pengantar Informatika \\
dan Ilmu Komputer, Manajemen, \\
Kewirausahaan. Universitas \\
Indraprasta PGRI Jakarta 12) 3) $^{2}$ \\
Email: Prasetio. \\
ariwibowo@yahoo.com
\end{tabular}

\section{History Artikel}

Received: Juni-2019;

Reviewed: Juli -2019

Accepted: Agustus-2019

Published: Agustus-2019
Abstrak. Tujuan kegiatan ini akan menambah wawasan
Pendidikan Karakter Pribadi, Kewirausahaan (Technopreneurship), Menemukan Peluang Usaha, Manajemen usaha, Peningkatan keterampilan, berupa pelatihan pembuatan produk seperti kuliner, kerajinan tangan, Musik, Fashion, Desain Komunikasi Visual, Aplikasi dan Game Developer, dan keahlian lainnya bagi segenap civitas akademik khususnya guru baik secara teori maupun aplikasi/praktik secara nyata yang akan dilakukan oleh para guru sendiri maupun peserta didik nya sehingga diharapkan para guru dapat menambah penghasilan dan membuka lapangan kerja bagi diri sendiri maupun orang lain. Khalayak sasaran kegiatan yang strategis dalam kegiatan ini adalah para peserta didik dan segenap civitas akademik lainnya dalam naungan Yayasan SMKS Bisnis dan Teknologi Bekasi. Jumlah peserta pelatihan sebanyak 30-50 orang yang terdiri dari segenap civitas akademik (Guru atau karyawan sekolah) baik yang berjenis kelamin pria dan wanita yang telah ditetapkan oleh pihak pengurus Yayasan SMKS Bisnis dan Teknologi Bekasi. Selama proses pelatihan, tim pelaksana kegiatan pengabdian melakukan pemantauan kepada peserta pelatihan sekaligus melakukan wawancara terhadap materi, metode dan instruktur dalam kegiatan ini. Secara umum, peserta abdimas (guru) mengatakan pelatihan ini sangat baik dan materi yang diberikan merupakan materi yang sangat dibutuhkan dalam kegiatan berwirausaha berbasis technopreneur sedangkan instrukturnya sangat berkompeten.

This work is licensed under a Creative Commons Attribution

4.0 International License

\section{PENDAHULUAN}

Di zaman millenial ini, ketika hampir semua aktivitas masyarakat menggunakan aplikasi teknologi mulai dari membuka mata hingga menutup mata kembali menyebabkan teknologi informasi dan komunikasi berkembang dengan sangat pesat dan sangat mempengaruhi segala aspek kehidupan manusia. Contoh paling sederhana adalah di dunia pendidikan, dampaknya sudah tak terelakkan lagi, yang merevolusi dalam segala aspek proses pembelajaran, riset, administrasi maupun pelayanannya kepada masyarakat. 
Pesatnya perkembangan teknologi baik hardware maupun software membuat praktisi pendidikan harus menyikapi dengan bijak. Bentuk penyikapan yang lazim adalah dengan memilah dan memilih software manakah yang layak digunakan guna mendukung proses perkembangan kepribadian peserta didik baik di lingkungan internal sekolah maupun eksternal sekolah.

Kewirausahaan merupakan salah satu mata pelajaran yang diajarkan pada peserta SMA/SMK/MA yang diajarkan pada peserta didik jurusan IPS yaitu sebagai mata pelajaran kewirausahaan dan prakarya, yang pada awalnya kewirausahaan ini masuk ke dalam materi ekonomi. Mata pelajaran kewirausahaan memiliki banyak peran yang sangat penting dalam perekonomian. Dengan adanya mata pelajaran kewirausahaan ini peserta didik dapat mengembangkan keterampilannya dalam membuka usaha dengan cara seperti menciptakan produk, memasarkan produk dan lain sebagainya. Selain itu pemberian mata pelajaran tersebut dapat menumbuhkan semangat serta pengetahuan akan kewirausahaan sejak dini dan merupakan langkah yang baik untuk menyiapkan wirausahawan muda di Indonesia.

Penanaman jiwa wirausaha pada setiap satuan pendidikan tidak harus sama, bisa dengan metode yang berbeda-beda sesuai karakter peserta didik masing-masing satuan pendidikan. Pada tingkatan SMA/SMK/MA, kewirausahaan bisa diintegrasikan dalam seluruh kurikulum, ekstra kurikuler, pengembangan diri, muatan lokal, dan sebagainya. Kemudian diwujudkan dalam Kegiatan Belajar Mengajar (KBM) dengan penyusunan silabus dan RPP yang terintegrasi pendidikan kewirausahaan. Kegiatan ekstra kurikuler dan pengembangan diri memiliki peluang yang cukup besar dalam penanaman kewirausahaan, sebab sekolah sepenuhnya bisa menentukan jenis kegiatan ekstra kurikuler dan pengembangan diri untuk peserta didiknya dan memiliki jam tersendiri yang lebih efektif dibandingkan penyisipan kewirausahaan dalam mata pelajaran pokok kedinasan maupun muatan lokal.

Mencetak wirausaha tentu tidak semudah membalikkan telapak tangan. Perlu sebuah sistem yang baik, dijalankan secara konsisten, di kontrol, dan ditanamkan sejak dini pada setiap insan Indonesia. Kurikulum yang diterapkan harus terintegrasi karakter kewirausahaan. Sehingga anak-anak sudah dikenalkan pada kewirausahaan sejak dini (khususnya satuan pendidikan tingkat SMA/SMK/MA). Sebenarnya hal ini sudah dicanangkan pemerintah dengan semangat membangun semangat kewirausahaan dan memperbanyak wirausaha melalui Instruksi Presiden Nomor 24 Tahun 1995 tentang Gerakan Nasional Memasyarakat dan Membudayakan Kewirausahaan. Program ini mengamanatkan kepada seluruh masyarakat dan bangsa Indonesia untuk membangun dan mengembangkan program-program kewirausahaan. Sehingga mendukung program pemerintah melalui Instruksi Presiden Nomor 6 Tahun 2009 tentang Pengembangan Ekonomi Kreatif, yang berhasil merumuskan Rencana Induk Pengembangan Ekonomi Kreatif Indonesia tahun 2009-2025 oleh Kementerian Perdagangan Republik Indonesia.

Dalam Rencana Strategis ini yang dimaksud dengan (1) Kreatifitas adalah kapasitas atau daya upaya untuk menghasilkan atau menciptakan sesuatu yang unik dan baru serta menciptakan solusi dari suatu masalah atau melakukan sesuatu yang berbeda; (2) Ekonomi Kreatif adalah penciptaan nilai tambah yang berbasis kreativitas; (3) Usaha Ekonomi Kreatif adalah entitas usaha baik yang berbadan hukum maupun tidak berbadan hukum yang mentransformasikan dan memanfaatkan kreatifitas untuk menghasilkan barang dan jasa serta yang diakui memiliki hak kekayaan intelektual baik terdaftar maupun melekat.

Dalam mewujudkan karakter kewirausahaan, tiap individu memiliki cara yang berbeda-beda, terdapat individu menggunakan skill entrepreneurshipnya yang apa adanya baik yang berdasarkan bakat, pengalaman pribadi, pengalaman orang tua, maupun mengikuti pelatihan-pelatihan yang apa adanya. Peringkat technopreneur yang paling diminati calon startup adalah program usaha kuliner, program software house IT, program souvenir dan lainnya (Tutik Khotimah, 2016).

Menurut Anwar (2004), life skill adalah pendidikan yang dapat memberikan bekal ketrampilan yang praktis terpakai, 
terkait dengan kebutuhan pasar kerja, peluang usaha dan potensi ekonomi atau industri yang ada di masyarakat. Broling (1989) dalam pedoman penyelenggaraan program kecakapan hidup pendidikan non formal mengelompokkan life skill menjadi tiga kelompok, yaitu: (1) Kecakapan hidup seharihari (daily living skill), antara lain meliputi : pengelolahan rumah pribadi, kesadaran kesehatan, kesadaran keamanan, pengelolahan makanan-gizi, pengelolahan pakaian, kesadaran pribadi warga negara, pengelolahan waktu luang, rekreasi, dan kesadaran lingkungan. (2) kecakapan hidup sosial/pribadi

(personall social skill), antara lain meliputi ; kesadaran diri (minat, bakat, sikap, kecakapan), percaya diri, komunikasi dengan orang lain, tenggang rasa dan kepedulian pada sesama, hubungan antar personal, pemahaman masalah, menemukan dan mengembangkan kebiasaan positif, kemandirian dan kepemimpinan. (3) kecakapan hidup bekerja (vocational skill), meliputi: kecakapan memilih pekerjaan, perencanaan kerja, persiapan keterampilan kerja, latihan keterampilan, pengusahaan kompetensi, menjalankan suatu profesi, kesadaran untuk menguasai berbagai keterampilan, kemampuan menguasai dan menerapkan teknologi, merancang dan melaksanakan proses pekerjaan, dan menghasilkan produk barang dan jasa.

Awalnya, teknologi diciptakan untuk mempermudah setiap kegiatan manusia.Teknologi lahir dari pemikiran manusia yang berusaha untuk mempermudah kegiatan-kegiatannya yang kemudian diterapkan dalam kehidupan. Kini teknologi telah berkembang pesat dan semakin canggih seiring dengan perkembangan zaman sehingga terjadi penambahan fungsi teknologi yang semakin memanjakan kehidupan manusia.Salah satu contoh fasilitas canggih saat ini adalah handphone.

Di awal kemunculannya, handphone hanya dimiliki oleh kalangan tertentu yang benar-benar membutuhkannya demi kelancaran pekerjaan mereka.Namun, seiring perkembangan zaman, handphone telah dimiliki oleh semua kalangan baik yang benar-benar membutuhkan maupun yang kurang membutuhkan tak terkecuali para remaja.

Kini handphone bukan lagi sekadar alat berkomunikasi, tetapi handphone juga merupakan alat untuk mencipta dan menghibur dengan suara, tulisan, gambar, dan video. Para remaja sekarang berlombalomba untuk memiliki handphone karena handphone bukan hanya merupakan alat berkomunikasi, namun juga di kalangan remaja handphone sekaligus sebagai gaya hidup, tren, dan prestise. Menurut Herman Purwono (2014), Media telepon tidak lagi menjadi hal yang awam, tetapi sudah menjadi hal biasa digunakan berbagai kalangan tanpa terkecuali siswa. Berdasarkan pengalaman penulis selama menempuh pendidikan di tingkat SMA, untuk mendapatkan skor yang memuaskan banyak siswa yang bahkan membuka ponsel.

Menurut Herwin Mopangga (2017), rendahnya daya saing produk UMK lokal disebabkan oleh penguasaan teknologi yang rendah. Inovasi seringkali bersifat jangka pendek hanya untuk pameran kewirausahaan di tingkat regional dan nasional, dan bukan untuk peningkatan kualitas produk, diversifikasi dan efisiensi produk, juga tidak untuk peningkatan keuntungan dan ekspansi pasar (Herwin Mopangga, 2017).

Garrido, Fierro, dan Navarro (2008) juga menyebutkan kecenderungan dalam abad ini adalah informasi dan teknologi informasi terus mengubah cara berbisnis, mengubah cara perusahaan bersaing dan merubah perilaku konsumen. Kemajuan teknologi informasi sebagai sebuah pemicu pengusaha-pengusaha dalam mengembangkan bisnisnya, karena faktor konsumen yang terbuka matanya dengan kemajuan teknologi.

Posadas (2007), mendefinisikan istilah technopreneurship dalam cakupan yang lebih luas, yakni sebagai wirausaha di bidang teknologi yang mencakup teknologi semikonduktor sampai ke aksesoris Komputer Pribadi (PC). Sebagai contoh adalah bagaimana Steven Wozniak dan Steve Job mengembangkan hobi mereka hingga mereka mampu merakit dan menjual 50 komputer Apple yang pertama, atau juga bagaimana Larry Page dan Sergey Brin mengembangkan karya mereka yang kemudian dikenal sebagai mesin pencari Google. Mereka inilah yang disebut sebagai para teknopreneur dalam definisi ini.

Sebelum era teknologi informasi dan komunikasi berkembang seperti sekarang ini, 
Caradde: Jurnal Pengabdian Kepada Masyarakat

Vol 2 No 1. Agustus 2019

penjualan sebuah produk hanya melalui sistem tatap muka antara penjual dengan pembeli. Dan tak jarang kita temui kebanyakan perusahaan hanya memanfaatkan teknologi sebagai sebuah pendukung (enabler) dalam menjalankan bisnisnya. Dewasa ini teknologi sudah berkembang dengan pesat dimana teknologi bukan lagi sebagai pendukung atau enabler, tetapi juga berkembang sebagai sebuah bagian paling penting dalam bisnis yang berjalan.

Cassidy (2002) menyatakan bahwa internet telah diadopsi jauh lebih cepat daripada teknologi-teknologi sebelumnya seperti, Televisi, PC (PersonalComputer), dan Radio. Hal tersebut menandai bahwa penggunaan internet meningkat jauh lebih cepat dengan jangka waktu paling singkat dibandingkan teknologi-teknologi lain. Dengan berkembangnya internet, masyarakat dapat dengan mudah mengakses situs jual beli online dan mendaftar sebagai komunitas seluruh forum. Hal ini membuat sebuah pangsa pasar baru yang kemudian dimanfaatkan oleh pengusaha-pengusaha muda yang baru saja memulai bisnisnya dengan mendapatkan massa lebih banyak.
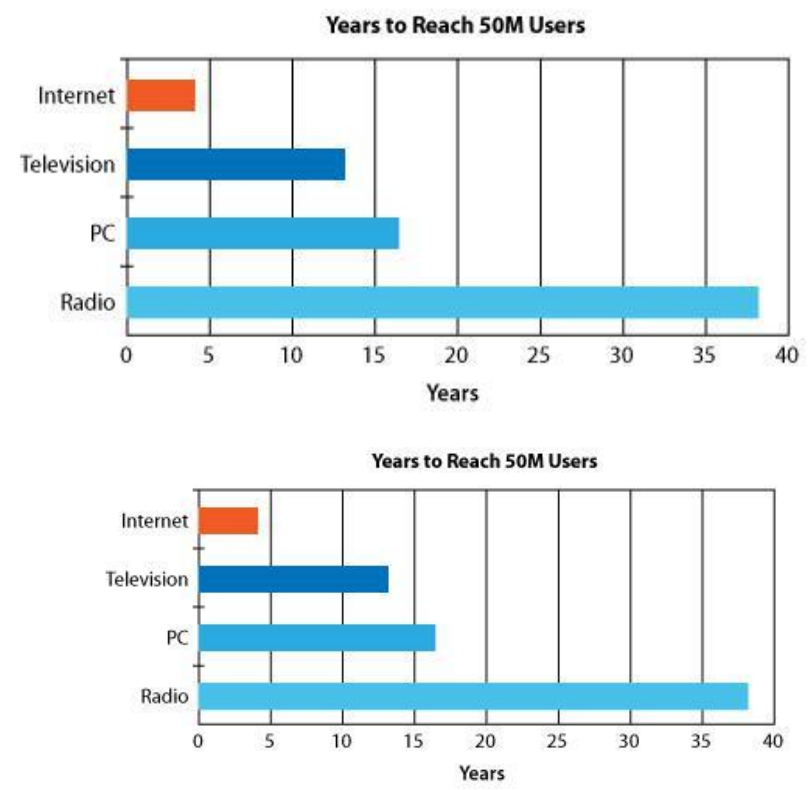

Gambar 1. Perkembangan Teknologi dalam Mencapai 50 Juta Pengguna (Sumber: Cassidy, 2002)

Cassidy (2002) juga mengungkapkan bahwa untuk mencapai 50 juta penggunaan teknologi yang dipakai, teknologi Radio membutuhkan waktu 38 tahun untuk mencapai 50 juta pengguna. Sedangkan, PC (Personal Computer) membutuhkan waktu 16 tahun lebih cepat, Televisi membutuhkan waktu 13 tahun agar penggunanya mencapai 50 juta, berbeda dengan internet yang hanya membutuhkan waktu 4 tahun agar penggunanya mencapai 50 juta. Internet telah berkembang dengan pesat, sehingga perusahaan-perusahaan yang bergerakdalam bidang barang maupun jasa berlomba-lomba dalam mendapatkan pasar dari dunia maya tersebut.

Pada umumnya, e-bisnis sendiri berbeda dengan e-commerce dan internet, internet merupakan sebuah sarana atau fasilitas, sedangkan e-commerce merupakan transaksi jual beli yang menggunakan internet sebagai sarana atau teknologi elektronik lain. Menurut Cassidy (2002) yang membedakan ebisnis dengan e-commerce ialah, e-bisnis merupakan penggabungan antara orangorang, proses dan teknologi dalam menghasilkan sebuah bisnis. Dengan menggunakan teknologi untuk membangun bisnis proses secara keseluruhan, hubungan atau relationships, dan perdagangan. E-bisnis bukan hanya mengenai website semata,tetapi mengenai keseluruhan bisnis model sebuah perusahaan yang menyangkut karyawan, pelanggan, dan pemasok. Berbeda dengan bisnis secara tradisional, e-bisnis dengan memanfaatkan teknologi yang digunakan seperti internet pada khususnya, membuat perusahaan dapat memperluas jaringan pasarnya sehingga keuntungan yang diperoleh dapat semakin besar.

Menurut Pavlou dan Gefen (2004), online marketplaces atau yang biasa disebut sebagai e-marketplaces adalah komunitaskomunitas yang tergabung antara pembeli dan penjual, dimana mereka saling bertukar informasi, berkoordinasi, dan bertransaksi menggunakan teknologi internet. Onlinemarketplaces dapat dibedakan menjadi dua kategori: business-to-business (B2B) marketplaces, yang memfasilitasi antar organisasi atau perusahaan, Business-toConsumer (B2C) atau Consumer-to-Consumer (C2C) marketplaces yangmemfasilitasi antar konsumen. Baik B2B maupun B2C atau C2C, kepercayaan adalah suatu faktor utama dalam mendukung jalannya bisnis, karena didalam online marketplace pembeli dan penjual tidak 
bertatap muka. Biasanya perusahaan yang bergerak dalam online marketplace memperhatikan hubunganantara pembeli dan penjual dengan memfasilitasi mereka dalam membangun kepercayaan satu sama lain.

Becker (2002) mengasumsikan bahwa penggunaan website terdiri dari beberapa komponen penting, salah satunya ialah tujuan strategis sebuah organisasi setelah menggunakan website. Website saat ini bukan lagi berisi informasi sebuah perusahaan dan profil perusahaan. Website saat ini terus berkembang menjadi sebuah media yang sangat kuat untuk menjadi sarana komunitas dalam berkumpul canda dan bertukar informasi antar anggota (member). Perkembangan website didominasi akan kebutuhan pasar yang membuat para developer mengkostumisasi website mereka agar dapat memiliki fitur-fitur yang berbeda, sehingga para pengguna website tersebut dapat sering mengunjungi website tersebut. Selain itu, keamanan atau sekuritas pada sebuah website merupakan kunci utama sebuah website dalam menjalankan transaksi baik itu transaksi jual beli maupun transaksi pertukaran data.

Chander, Kush, dan Sharmila (2012) menyatakan dengan berkembangnya situs dan web secara exponensial, keamanan menjadi masalah utama. Semakin banyaknya layanan yang online maka semakin tinggi resiko kehilangan informasi sejalan dengan munculnya berbagai kekhawatiran mengenai keamanan. Perkembangan website saat ini sudah bisa menutupi hampir semua fungsi layanan yang diberikan kepada masyarakat.

Hasley dan Greg (2010) menjelaskan

bahwa Internet pada dasarnya media informasi, dan kebanyakan bisnis beroperasi secara online menyediakan informasi yang dirancang untuk meningkatkan kemampuan pengunjung dalam membuat keputusan. Dengan peningkatan fitur website yang sudah semakin berkembang dan lengkap, penggunaan website tidak lagi sebagai media informasi semata, tetapi juga dilengkapi dengan alat bantu atau decision maker dalam memilih barang atau jasa yang akan dibeli oleh pengguna. Pengguna tidak lagi harus bertanya dengan penjaga toko online tersebut ataupun menelpon penjual dalam menanyakan barang ataupun jasa yang akan dibeli.
Dalam memulai bisnis secara online, diperlukan juga pengetahuan dalam meningkatkan brand perusahaan bisnis yang akan dibangun demi memenangkan persaingan. Sebuah brand atau merek haruslah mengundang pengguna untuk menggunakan produk tersebut. Harris dan Dennis (2002), mengemukakan bahwa sebuah merek atau brand dapat memberikan 4 tingkatan makna: (1) Attributes, sebuah merek yang kuat akan dapat selalu diingat oleh konsumen, dengan penambahan atribut seperti tagline dan kata-kata lain yang menyimpan sebuah kalimat pendek tetapi menggambarkan makna yang tinggi; (2) Benefits, dalam hal ini konsumen tidak membeli atribut yang terpampangdiproduk yang ingin dijual, melainkan mereka membeli benefit atau keuntungan yang mereka peroleh; (3) Values, sebuah merek tentu harus memiliki nilai yang dapat dibanggakanatau membuat konsumen ingin membeli produk tersebut daripada produk yang lain; (4) Personality, sebuah merek harus mempunyai karakter yang kuat, apakahkarakter itu cocok untuk target konsumen berjiwa muda atau untuk ibu-ibu hamil dan mungkin cocok untuk semua kalangan masyarakat

Pembentukan merek secara online dengan bantuan media internet memang bersifat global dan dapat digunakan secara internasional, namun sebuah culture yang ada dilingkungan dimana perusahaan tersebut berada juga sangat mempengaruhi produktivitas perusahaan. Perusahaan harus bisa beradaptasi dengan lingkungan sekitar terlebih dahulu karena strategi marketing (marketingmix) yang digunakan disesuaikan dengan kondisi sekitar dengan menekankan 4tingkatan dari attributes, benefits, values dan personality.

Di zaman now, menggunakan teknologi komunikasi, seperti handphone dan internet sebagai alat multifungsi karena multifungsinya tersebut para remaja dapat menggunakan teknologi ini secara positif ataupun negatif tergantung setiap individu. Contoh positif dari penggunaan teknologi komunikasi adalah memanfaatkan teknologi ini untuk membantu mereka dalam proses perkembangan karakter/kepribadian peserta didik (khususnya technopreneurship soul). Namun, ada beberapa hal yang perlu dikhawatirkan dalam pemanfaatan teknologi 
Caradde: Jurnal Pengabdian Kepada Masyarakat Vol 2 No 1. Agustus 2019

komunikasi oleh para remaja seperti penggunaan tidak sesuai kondisi, menggunakan handphone dalam proses perkembangan karakter peserta didik di masa yang akan atang misalnya.

Menurut Cassidy (2002), terdapat pengaruh positif dari perkembangan teknologi, yaitu:

1. Dengan adanya internet para remaja dapat berkomunikasi dengan pengguna lainnya dari seluruh dunia.

2. Dengan adanya internet sebagai media pertukaran data, dengan menggunakan email user dapat saling bertukar informasi dengan cepat dan murah.

3. Mempermudah proses pembelajaran bagi user khususnya dibidang pendidikan.

4. Mempermudah komunikasi untuk menyambung silaturrahmi antar user satu dengan lainnya.

5. Memudahkan user untuk bertransaksi dan berbisnis dalam bidang perdagangan sehingga tidak perlu pergi ke tempat penawaran atau penjualan.

6. User tidak gagap teknologi, remaja dapat mengikuti perkembangan Era Teknologisasi Dunia sehingga user lebih produktif.

Berikut beberapa dampak negatif dari perkembangan teknologi bagi remaja (Cassidy, 2002) :

1. User akan sering mengunjungi situs-situs yang berbau pornografi.

2. Dengan adanya internet, akan dijadikan ajang perjudian online dikalangan user.

3. Terjadinya banyak penipuan dikalangan remaja khususnya dibidang transaksi jual beli online.

4. Menimbulkan banyaknya kejahatan yang terjadi seperti penculikan, pemerkosan dll.

Istilah Ekonomi Kreatif pertama kali diperkenalkan oleh tokoh bernama John Howkins, penulis buku "Creative Economy, How People Make Money from Ideas". Jhon Howkins adalah seorang yang multi profesi. Menurut definisi Howkins, Ekonomi Kreatif adalah kegiatan ekonomi dimana input dan outputnya adalah Gagasan. Benar juga, esensi dari kreatifitas adalah gagasan. Bayangkan hanya dengan modal gagasan, seseorang yang kreatif dapat memperoleh penghasilan yang sangat layak. Gagasan seperti apakah yang dimaksud? Yaitu gagasan yang orisinil dan dapat diproteksi oleh HKI. Contohnya adalah penyanyi, bintang film, pencipta lagu, atau periset mikro biologi yang sedang meneliti farietas unggul padi yang belum pernah diciptakan sebelumnya (Anggraini, 2008).

Di Indonesia terdapat berbagai macam sektor, salah satunya sektor industri. Dalam menjalankan kegiatan perindustrian, terdapat beberapa kendala dan keberhasilan yang dicapai oleh industri kreatif yaitu sebagai berikut:

\section{Kendala Industri Kreatif}

a. Masih kurangnya sumber daya manusia yang mengembangkan industri kreatif.

b. Industri kreatif mengalami kesulitan dalam distribusi dan pemasanan produk.

c. Peraturan pemerintah yang berkaitan dengan industri kreatif masih kurang tegas dan jelas Pemberian bantuan dan proses pendanaan untuk memperoleh modal dan pinjaman bagi pelaku industri kreatif masih sangat kurang.

2. Keberhasilan Industri Kreatif

a. Ada perubahan cara berfikir dan strategi dalam pengembangan industri kecil.

b. Ada ketersediaan sarana dan prasarana melakukan kegiatan kreatif.

c. Ada peraturan pemerintah yang mengatur dan menata industri kreatif.

d. Ada saling interaksi yang dilakukan antara pemerintah, lembaga, akademisi, dan pelaku industri kreatif.

e. Ada pembuatan roadmap industri kreatif yang merencanakan pola, strategi dan konsep pengembangan usaha dalam jangka pendek, jangka menengah dan jangka panjang

Pelatihan keterampilan pada kegiatan ini termasuk dalam kategori pendidikan luar sekolah (PLS). Seperti yang dikatakan Harbinson (Saleh, 2010 : 104) bahwa pendidikan luar sekolah dapat diklasifikasikan menjadi tiga, yaitu: 1 . kegiatan yang berorientasi pada pengembangan pengetahuan, keterampilan, dan sikap para pekerja; 2. kegiatan untuk mempersiapkan generasi muda untuk bekerja; dan 3. kegiatan yang dirancang untuk mengembangkan pengetahuan, keterampilan dan sikap orang terlepas dari dunia kerja.

Adapun salah satu tujuan dari program pendidikan luar sekolah adalah 
kemampuan produktif, yang mana kemampuan produktif ini dapat diperoleh melalui pelatihan keterampilan.

Arkeolog (UGM), Atmosudiro, dkk, memerinci bahwa seni kriya (craft) adalah semua hasil karya manusia yang memerlukan keahlian khusus yang berkaitan dengan tangan, sehingga kriya sering disebut kerajinan tangan. Seni kriya dihasilkan melalui keahlian manusia dalam mengolah bahan mentah, menjadi produk dan ruang lingkupnya dapat ditelusuri melalui bahan yang dipergunakan tersebut, diantaranya batu, tanah liat, kayu, logam, benang, tulang, cangkang kerang, kulit, kaca, dedaunan, buah kering, plastik, serat, dll. Seni kriya juga dapat dikelompokkan menurut tujuan penciptaannya dan kegunaannya menjadi fungsi praktis, estetis, simbolis dan religius (Atmosudiro, 2001: 107-110).

Sebagai salah satu lembaga pendidikan yang mendidik calon tenaga edukatif dan calon entrepreneur handal yang peduli, mandiri, dan kreatif, tim bims perlu berperan serta dalam pembentukan karakter internet/teknologi user, khususnya para guru di kalangan SMA/SMK/MA dalam menangani permasalahan penerapan pendidikan kewirausahaan terhadap karakter peserta didik baik secara teori maupun praktik. Berdasarkan hal tersebut, para civitas akademik yang menjadi mitra pengabdian kepada masyarakat ini perlu dibekali dengan berbagai macam keterampilan technopreneurship untuk menghadapi tantangan masa depan.

Permasalahan mitra dalam kegiatan ini adalah :

1. Peluang usaha yang relatif terbatas

2. Minimnya pengetahuan yang diperoleh civitas akademik khususnya guru mengenai kewirausahaan khususnya technopreneurship yang baik dan benar.

3. Belum optimalnya terciptanya usaha ekonomi produktif.

4. Rendahnya para guru dalam mengeksploitasi unsur-unsur positif dan lebih cenderung mengakses berbagai perihal negatif dari perkembangan teknologi. adalah :

Solusi dari kegiatan abdimas ini

1. Melalui kegiatan Abdimas ini dapat merubah pola pikir masyarakat mengenai alternatif usaha sehingga dapat meningkatkan kesejahteraan masyarakat khususnya para civitas akademik di sekolah SMKS Bisnis dan Teknologi Bekasi.

2. Menekan jumlah civitas akademik untuk mengakses berbagai konten negatif dan memberikan pengetahuan akan pentingnya dan tata cara dalam mengakses pelbagai konten positif dari kemajuan teknologi di masa yang akan datang.

3. Membekali para civitas akademik lainnya untuk memiliki jiwa kewirausahaan terutama technopreneurship dalam mengembangkan usaha ekonomi kreatif baik secara teori maupun praktik.

4. Memberi pemahaman mengenai kewirausahaan technopreneurship sebagai modal awal dalam mengembangkan usaha. Bentuk kegiatannya adalah pelatihan motivasi berusaha dan technopreneurshipbaik secara teori maupun praktik.

5. Mengembangkan usaha ekonomi produktif dalam bentuk Kelompok Usaha Bersama yang didasarkan pada potensi kelompok dari masing-masing civitas akademik baik secara teori maupun praktik.

Dalam rangka mencapai tujuan/ Solusi dari kegiatan abdimas ini, maka ditempuh langkah-langkah sebagai berikut :

1. Menghubungi Ketua yayasan SMKS Bisnis dan Teknologi Bekasi.

2. Menyelenggarakan pelatihan, dengan materi: Pendidikan Karakter Pribadi, Kewirausahaan (Technopreneurship), Menemukan Peluang Usaha, Manajemen usaha, Peningkatan keterampilan, berupa pelatihan pembuatan produk yang disesuaikan dengan potensi siswa sekolah seperti kuliner, kerajinan tangan, Musik, Fashion, Desain Komunikasi Visual, Aplikasi dan Game Developer, dan keahlian lainnya.

3. Untuk menilai keberhasilan program kegiatan ini adalah $85 \%$ peserta yang diundang hadir dalam pelatihan., Terlaksananya seluruh kegiatan pelatihan Kewirausahaan (Technopreneurship), $\quad 50 \%$ peserta mampu mengembangkan usaha 
Caradde: Jurnal Pengabdian Kepada Masyarakat

Vol 2 No 1. Agustus 2019

ekonomi produktif dengan pendampingan dari tim pengabdi berupa peserta dapat menghasilkan produk bernilai ekonomis sebagai sumber penghasilan sehingga peserta abdimas tidak kembali mencari "rejeki" dengan bergantung kepada orang tua, orang lain, dan apat membuka lapangan kerja bagi diri sendiri dan orang lain di masa mendatang, Pernyataan kepuasan dari peserta pelatihan dan segenap civitas akademik yayasan/sekolah SMKS Bisnis dan Teknologi Bekasi.

\section{METODE}

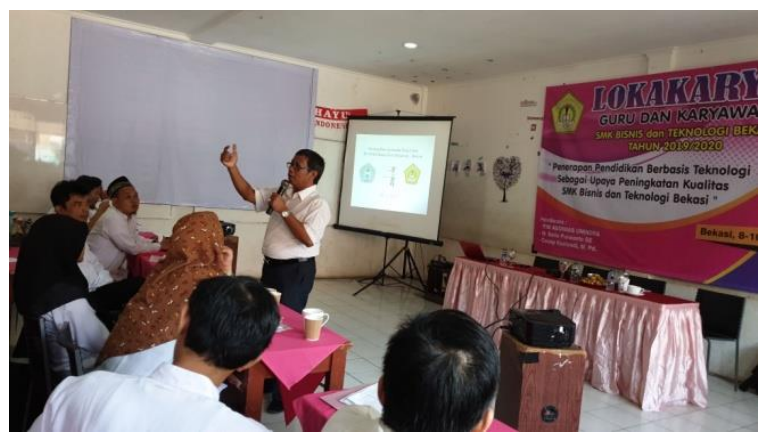

Gambar 2. Rekapitulasi Tanggapan Pemateri abdimas Terhadap Peserta (Hari Pertama)

Dalam rangka mencapai tujuan abdimas, maka ditempuh langkah-langkah kegiatan abdimas sebagai berikut :

1. Menghubungi Ketua yayasan SMKS Bisnis dan Teknologi Bekasi untuk mendiskusikan topik yang hendak diabdikan yaitu pemberdayaan usaha ekonomi produktif khususnya mengenai technopreneurbagi segenap civitas akademik sekolah SMKS Bisnis dan Teknologi Bekasi khususnya Guru, siswa kelas XI dan XII sebagai calon peserta abdimas.

2. Menyelenggarakan pelatihan, dengan materi:

a. Pendidikan Karakter Pribadi

b. Kewirausahaan (Technopreneurship)

c. Menemukan Peluang Usaha

d. Manajemen usaha

e. Peningkatan keterampilan, berupa pelatihan pembuatan produk yang disesuaikan dengan potensi siswa sekolah seperti kuliner, kerajinan tangan, Musik, Fashion, Desain
Komunikasi Visual, Aplikasi dan Game Developer, dan keahlian lainnya.

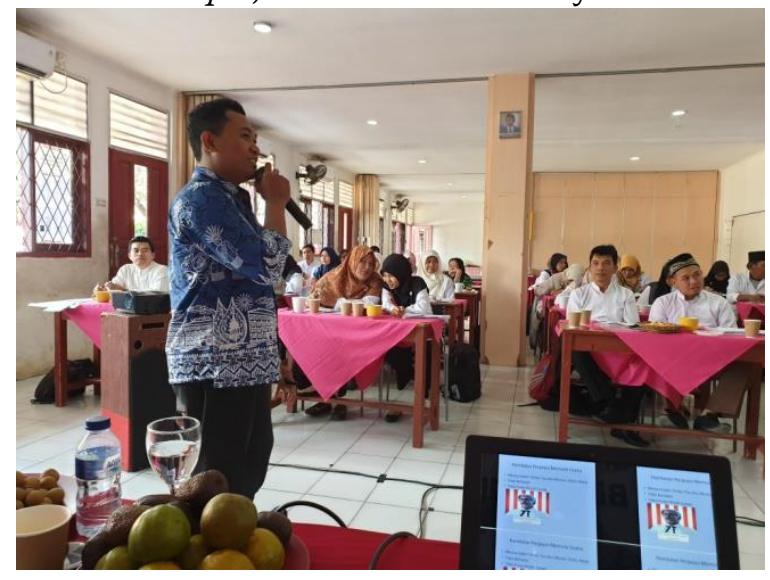

Gambar 3. Pemateri abdimas Terhadap Peserta (Hari kedua)

3. Untuk menilai keberhasilan program kegiatan ini adalah :

a. $85 \%$ peserta yang diundang hadir dalam pelatihan..

b. Terlaksananya seluruh kegiatan pelatihan Kewirausahaan (Technopreneurship).

c. $50 \%$ peserta mampu mengembangkan usaha ekonomi produktif dengan pendampingan dari tim pengabdi berupa peserta dapat menghasilkan produk bernilai ekonomis sebagai sumber penghasilan sehingga peserta abdimas tidak kembali mencari "rejeki" dengan bergantung kepada orang tua, orang lain, dan apat membuka lapangan kerja bagi diri sendiri dan orang lain di masa mendatang.

d. Pernyataan kepuasan dari peserta pelatihan dan segenap civitas akademik yayasan/sekolah SMKS Bisnis dan Teknologi Bekasi.

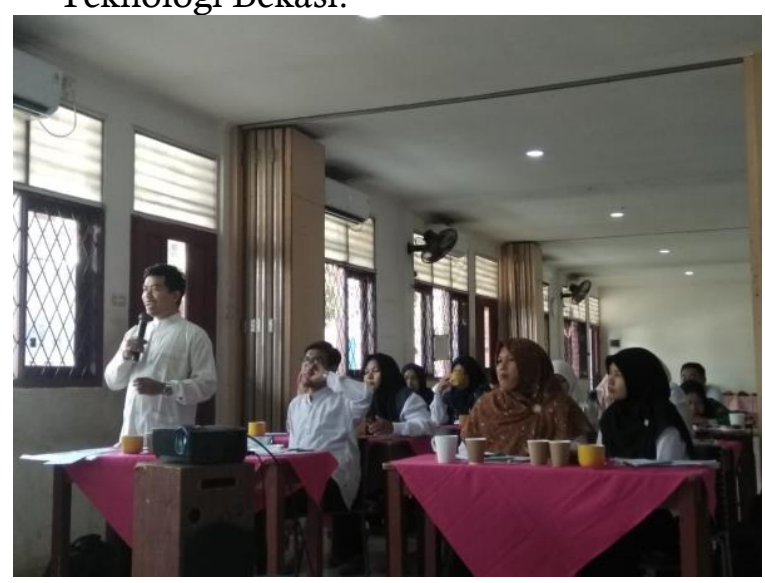

Gambar 4. Sesi Tanya Jawab Peserta Terhadap Pemateri abdimas 


\section{HASIL DAN PEMBAHASAN}

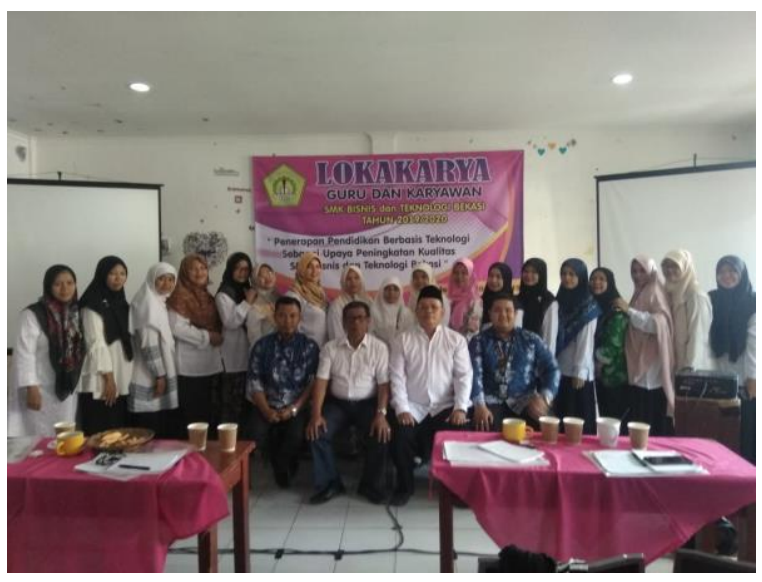

Gambar 5. Foto Bersama antara Pemateri abdimas dengan Peserta

Selama proses pelatihan hari pertama, tim pelaksana kegiatan pengabdian melakukan pemantauan kepada peserta pelatihan sekaligus melakukan wawancara terhadap materi, metode dan instruktur dalam kegiatan ini. Secara umum guru mengatakan pelatihan ini sangat baik dan materi yang diberikan merupakan materi yang sangat dibutuhkan dalam kegiatan berwirausaha berbasis technopreneur sedangkan instrukturnya sangat berkompoten.

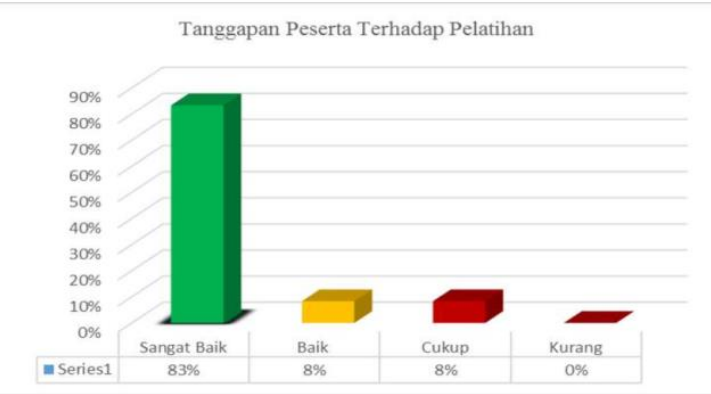

Gambar 6. Rekapitulasi Tanggapan Peserta Terhadap Pemateri abdimas (Hari Pertama)

Selama proses pelatihan hari kedua, tim pelaksana kegiatan pengabdian melakukan pemantauan kepada peserta pelatihan sekaligus melakukan wawancara terhadap materi, metode dan instruktur dalam kegiatan ini. Secara umum pesertaabdimas mengatakan pelatihan ini sangat baik dan materi yang diberikan merupakan materi yang sangat dibutuhkan dalam kegiatan
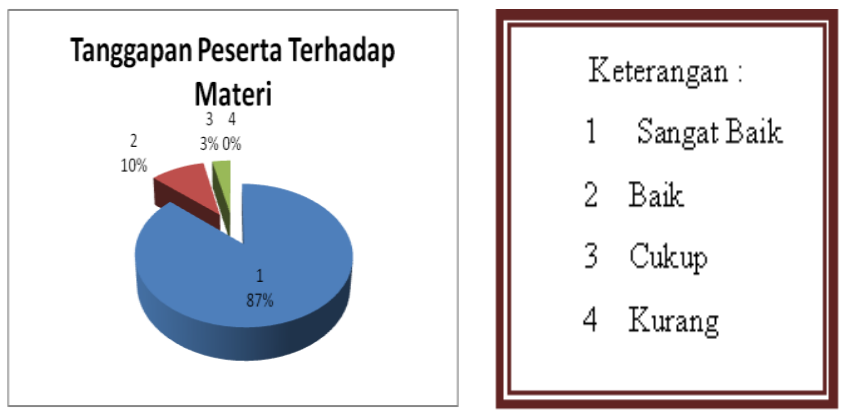

Gambar 8. Rekapitu lasi Tanggapan Peserta Terhadap Materi abdimas (Hari Kedua)

Berwirausaha berbasis technopreneur sedangkan instrukturnya sangat berkompoten terutama secara praktik dari semua teori yang telah diperoleh pada pertemuan pertama.
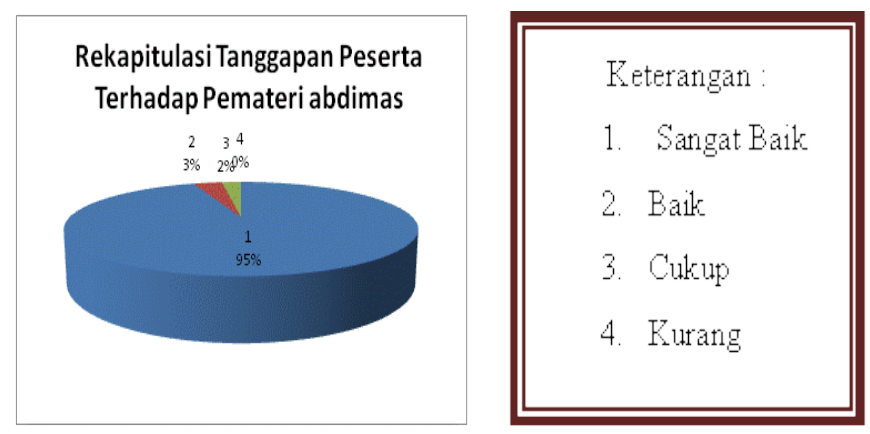

Gambar 7. Rekapitulasi Tanggapan Peserta Terhadap Pemateriabdimas (Hari Kedua)

Tahapan pelaksanaan pengabdian yang sudah dilakukan sampai saat ini adalah pada tahapan pelatihan guru/peserta dalam menciptakan dan mengembangkan potensi jiwa kewirausahaan yng dimiliki dalam setiap peserta.

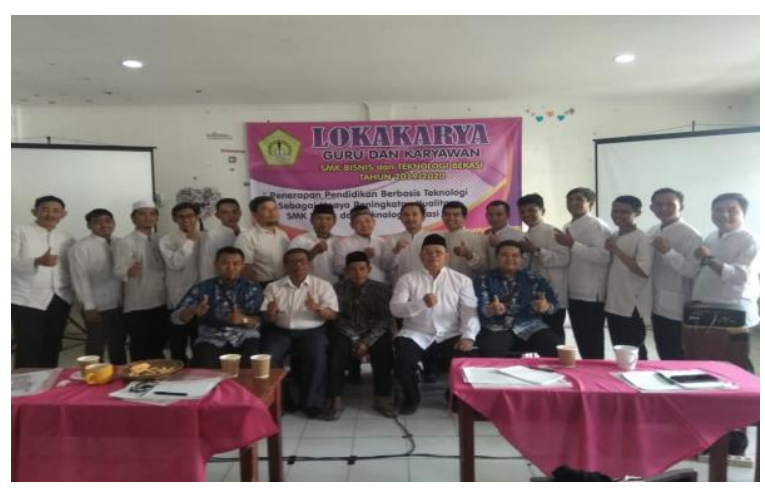

Gambar 9. Foto Bersama antara Pemateri abdimas dengan Peserta 
Caradde: Jurnal Pengabdian Kepada Masyarakat

Vol 2 No 1. Agustus 2019

Hasil yang diharapkan pada tahap ini adalah guru/peserta abdimasmampu menghasilkan startup-startup usaha baru baik di bidang technopreneur maupun non technopreneur. Pada tahapan selanjutnya adalah pendampingan secara periodik 2 minggu sekali terhadapguru/peserta abdimas dalam menyusun dan menjalankan business plan yang sesuai dengan "soul" masingmasing peserta selama 3 bulan ke depan.

\section{SIMPULAN DAN SARAN}

Berdasarkan hasil pengabdian masyarakat yang telah dilaksanakan (1) proses pelatihan hari pertama, secara umum guru mengatakan pelatihan ini sangat baik dan materi yang diberikan merupakan materi yang sangat dibutuhkan dalam kegiatan berwirausaha berbasis technopreneur sedangkan instrukturnya sangat berkompeten. (2) Selama proses pelatihan hari kedua, peserta abdimas mengatakan pelatihan ini sangat baik dan materi yang diberikan merupakan materi yang sangat dibutuhkan dalam kegiatan berwirausaha berbasis technopreneur sedangkan instrukturnya sangat berkompoten terutama secara praktik dari semua teori yang telah diperoleh pada pertemuan pertama.

Adapun saran dalam PKM ini adalah (1) Hendaknya pembahasan dilakukan lebih mendalam atau fokus untuk pembahasannya untuk mempermudah bagi pesertaabdimas (PKM) dalam memahami materi yang akan dipelajari; (2) Waktu pelaksanaan hendaknya diperbanyak/ditambah pada periode PKM berikutnya; (3) Perbanyak mengundang praktisi yang benar-benar ahli di bidangnya; (4) Peserta PKM hendaknya yang benar-benar berniat maupun telah memiliki usaha.

\section{DAFTAR RUJUKAN}

Anggraini, Nenny. 2008. Industri Kreatif. Jurnal ekonomi. Edisi Desember 2008, Volume XIII No. 3 hal. 144151.

Anwar. 2004. Pendidikan Kecakapan Hidup (Life Skill Education). Bandung : Alfabeta.
Atmosudiro, Sumijati, dkk. 2001. Jawa Tengah : Sebuah Potret Warisan Budaya. Prambanan, Klaten : Balai Pelestarian Peninggalan Purbakala Jawa Tengah bekerjasama dengan Jurusan Arkeologi, Fakultas Ilmu Budaya, Universitas Gadjah Mada. Cetakan Pertama.

Atmosudiro, Sumijati, dkk. 2008. Jawa Tengah : Sebuah Potret Warisan Budaya. Prambanan, Klaten : Balai Pelestarian Peninggalan Purbakala Jawa Tengah bekerjasama dengan Jurusan Arkeologi, Fakultas Ilmu Budaya, Universitas Gadjah Mada. Edisi Revisi - Cetakan Ketiga, 244 Halaman.

Brolinh, D.E 1989. Life Centered Education A Competency Based Approach.Reston VA. The Council for Exeptional Children

Cassidy, A. 2002. A Partial Guide to Planning for E-Business Success How to E-Enable Your Enterprise. Florida : St. Lucie.

Chander, S., \& Kush, A. (2012). Vulnerability in Web Page and Web Sites. International Journal of Advanced Research in IT and Engineering. Vol. 1 | No. 2 | August 2012, 47 57.

Garrido, Jose A. Medina.Fierro, Salustiano Martinez. Navarro, Jose Ruiz. 2008. Cases on Information Technology Entrepreneurship. IGI Publishing.

Harris, Lisa and Dennis, Charles. 2002. Marketing The E-Business. New York : Routledge, Taylor \& Francis Group.

Hasley, J., \&Gregg, D. 2010. An Exploratory Study of Website Information Content. Journal of Theoretical and Applied Electronic Commerce Research, Vol. 5 No. 3, 27-38.

Herwin Mopangga. 2017. Technopreneurship Untuk Pembelajaran Dan Pemberdayaan Ekonomi Lokal Di Provinsi Gorontalo. Seminar Nasional \& Call For Paper, FEB Unikama 
Haryono $^{1}$, Ariwibowo², Djuhartono ${ }^{3}$. PKM Ekonomi Produktif

"Peningkatan Ketahanan Ekonomi Nasional Dalam Rangka Menghadapi Persaingan Global". Malang, 17 Mei 2017.

Pavlou, P.A and Gefen.D. 2004. Building Effective Online Marketplaces with Institution-Based Trust. Information Systems Research. Vol. 15, No. 1, March 2004, pp. 37-59.

Pemerintah Republik Indonesia. 1995. Instruksi Presiden No. 4 Tahun 1995 Tentang Gerakan Nasional Memasyarakatkan dan Membudayakan Kewirausahaan (GNMMK). Jakarta: Pemerintah Republik Indonesia.

Pemerintah Republik Indonesia. 2015. Peraturan Pemerintah No. 72 Tahun 2015 Tentang Perubahan Atas Peraturan Presiden Nomor 6 Tahun 2015 Tentang Badan Ekonomi Kreatif. Jakarta: Pemerintah Republik Indonesia.
Posadas, D. 2007. Rice and Chips: Technopreneurship and Innovation in Asia. Singapore : Prentice Hall Inc.

Purwono, Herman. 2014. Pengaruh Handphone dan Tingkat Kedisiplinan Belajar terhadap Perilaku Menyontek. Education Vitae Journal Vol. 1/Tahun 1/2014. Page 39- 57 .

Republik Indonesia. 2009. Instruksi Presiden No. 6 tahun 2009 tentang Pengembangan Ekonomi Kreatif. Jakarta.Rosdakarya. 